Citation: Rosales-Nieto, C. A., Cuevas-Reyes, V., Sánchez-Toledano, B. I., \& Borja-Bravo, M. (2021). Determinants of artificial insemination use in cattle in northern Sinaloa, Mexico. Agro Productividad. https://doi. org/ 10.32854/agrop.vl4il2.1998

Editor in Chief: Dr. Jorge Cadena Iñiguez

Received: April 15, 2021. Accepted: November 23, 2021. Published on-line: December 20, 2021

This work is licensed under a Creative Commons Attribution-NonCommercial 4.0 International license.

\section{Determinants of artificial insemination use in cattle in northern Sinaloa, Mexico}

\author{
Rosales-Nieto, Cesar A. ${ }^{1}$; Guevas-Reyes, Venancio ${ }^{2 *}$; Sánchez-Toledano, Blanca I. ${ }^{3}$; \\ Borja-Bravo, Mercedes ${ }^{4}$
}

1 Universidad Autónoma de San Luis Potosí, Facultad de Agronomía y Veterinaria, Carretera San LuisMatehuala km 14.5, Soledad de Graciano Sánchez, San Luis Potosí, S.L.P., México, C. P. 78321.

2 Instituto Nacional de Investigaciones Forestales, Agrícolas y Pecuarias (INIFAP), Campo Experimental Valle de México, Carretera Los Reyes-Texcoco km 13.5, Coatlinchán, Texcoco, Estado de México, México, C. P. 56250.

3 INIFAP, Campo Experimental Zacatecas, CIR-Norte Centro, Carretera Zacatecas-Fresnillo km 24.5, Calera, Zacatecas, México, G. P. 98500.

4 INIFAP, Campo Experimental Pabellón, CIR-Norte Centro, Carretera Zacatecas-Aguascalientes km 32.5, Pabellón de Arteaga, Aguascalientes, México, C. P. 20660.

* Correspondence: cuevas.venancio@inifap.gob.mx

\begin{abstract}
Objective: To identify the factors that determine the use of artificial insemination by cattle producers in northern Sinaloa.

Design/methodology/approach: We used a discrete-choice logit model for 200 cattle producers from northern Sinaloa.

Results: Four variables were significant $(\mathrm{p} \leq 0.05)$ : two of them reduce the probability that the farmer will adopt the artificial insemination technology (age and distance from the ranch to the municipality), while the other two increase the probability of adoption (income from the sale of calves and machinery and equipment index).

Limitations/implications: The results only apply to the sample from three municipalities in northern Sinaloa, although they may be useful for other regions with similar characteristics.

Findings/conclusions: Farmers with a higher rate of machinery and equipment have a $36.43 \%$ probability of adoption.
\end{abstract}

Keywords: dry tropics, genetic improvement, technological adoption.

\section{INTRODUCTION}

Animal production systems in tropical areas can contribute to a greater demand for food of animal origin; these systems have the best conditions to increase food production, based on their ability to generate biomass (Chará et al., 2015). In tropical areas, livestock is characterized by the production of milk or cheese and animals for slaughter (Urdaneta, 2019); consequently, this dual-purpose cattle production system is called "Sistemas Bovinos de Doble Propósito (SBDP)". In Mexico, SBDPs are associated with a tropical vegetation 
area of 28.3 million hectares (INEGI, 2019) and a 13\% contribution to the national milk production (SIAP, 2020).

The productivity of tropical livestock herds in Mexico is below 50\% of their biological capacity (REDGATRO, 2018). In other words, this type of livestock - due to its current conditions - has a high productive potential. Therefore, the improvement of reproductive efficiency is an important step to achieve this potential and to maximize the profitability of the said system (Horrach et al., 2020).

Artificial insemination (IA) is an assisted reproductive technology that generates an accelerated genetic gain that affects the productive, reproductive, and collective performance of the cattle herd, potentially increasing the beef and dairy production (Kubkomawa, 2018; Baruselli et al., 2018). Despite these benefits, few farmers have used and adopted this technology.

In Mexico and other countries, 4-15\% of the farmers use this technology (Kubkomawa, 2018; Baruselli et al., 2019; Lassala et al., 2020). In the state of Sinaloa, "livestock is based on undefined crossbreds and it is not focused on productive improvement, which results in low-weight calves at birth, low fattening performance, and low-quality carcasses" (Casillas, 2012, p. 8). Faced with this problem, for more than 20 years, local research centers have implemented projects to promote the use of various technologies (including IA), in the dual-purpose cattle system prevalent in the state of Sinaloa (Loaiza, 2011).

Some studies have used diagnoses to identify the percentage of producers that use IA in the tropical regions of Mexico (Basurto et al., 1997; Cuevas et al., 2013; Rangel et al., 2017 , 2020). However, in general there have not been many studies that identify the factors that determine the use of IA; specifically, there are no studies of this type in northern Sinaloa. Perhaps the low use of this technology in the study region can be explained by the excessive (economic, technical, and human) requirements and inputs (such as nitrogen). The objective of this work is to identify the factors that determine the use of artificial insemination by cattle producers in northern Sinaloa.

\section{MATERIALS AND METHODS}

\section{Location of the study area}

The study was carried out in the state of Sinaloa in northwestern Mexico. Sinaloa is located between the following geographic coordinates: $27^{\circ} 02^{\prime} 32^{\prime \prime} \mathrm{N}, 22^{\circ} 28$ ' $02^{\prime \prime} \mathrm{S}, 105^{\circ}$ $23^{\prime} 32^{\prime \prime} \mathrm{E}$, and $109^{\circ} 26^{\prime} 52^{\prime \prime} \mathrm{W}$. The weather in the state is divided as follows: $37.14 \%$ has a warm sub-humid climate with rainfall in summer $\mathrm{A}(\mathrm{w}) ; 21.27 \%$ has a semi-arid climate that is very hot and hot $\mathrm{BS} 1$ (h'); and $18.56 \%$ has an arid climate that is very hot and hot BS0 (h'). In the upper parts of the Sierra Madre Occidental (2.26\%), Sinaloa has a temperate sub-humid climate with rainfall in summer (INEGI, 2017).

\section{Instrument used}

The information was obtained through a survey aimed at the producers who participated in the Proyecto Integral de Innovación y Extensionismo Rural (PIIEX): "Bovinos doble propósito". The project was financed by the Secretaría de Agricultura, Ganadería, Desarrollo Rural, Pesca y Alimentación (SAGARPA). The survey was carried out from 
September to November 2015. Nevertheless, the analysis of the variables that determine the use of IA in dual-purpose cattle is still valid, because there is no information on the subject for the region.

A sample of $n=200$ producers was obtained through non-probabilistic sampling in three municipalities in the north of Sinaloa (Ahome, El Fuerte, and Guasave). The following criteria were used to select the producers: 1) the producer owned cattle; 2) the producer had not been a beneficiary of government programs in previous years; and 3) the producer agreed to answer the survey. The information we obtained included the age, educational level, and number of children of the producer, as well as farm-related aspects (cattle herd and constructions, as well as machines and equipment). The information also covered commercialization, context variables, rural extension services, and distance from the productive unit to the municipality, among others. Cuevas-Reyes and Rosales-Nieto (2018) further described the calculation of the infrastructure, machinery and equipment index.

\section{Econometric model and variables}

A discrete-choice logit model was used to estimate the factors that determine the use of IA. These models use a binary categorical variable with two mutually exclusive categories which can be expressed by numerical values of 1 and 0 (Greene, 2003). The model assumes that there is a $Y_{i}$ variable that measures the use of the IA by the $i$-th farmer expressed in the following formula: $Y_{i}=X_{i}^{\prime} \theta+U_{i}$. Where $X_{i}^{\prime}$ is a vector of the explanatory variables, $\theta$ is an unknown parameter that must be estimated, and $U_{i}$ is the stochastic term. In this model, the $Y_{i}$ dependent variable is binary and has two values: $Y_{i}=1$ (if the farmer uses IA) and $Y_{i}=0$ (otherwise). Therefore, the binary logistic regression model is given by the following equation (Cameron et al., 2005):

$$
p_{i}=\operatorname{Pr}\left[y_{i}=1 \mid x_{i}\right]=\frac{\exp \left(x_{i} \beta_{i}\right)}{1+\exp \left(x_{i} \beta_{i}\right)}
$$

This ensures that the probability is between 0 and 1 . The logit model marginal effects are given by the following equation, that is commonly known as the probability density function of the logistic distribution, multiplied by the coefficient of the explanatory variable under consideration (Cameron et al., 2005):

$$
\frac{d p_{i}}{d x_{i}}=\frac{\exp \left(x_{i} \beta_{i}\right)}{\left(1+\exp \left(x_{i} \beta_{i}\right)\right)^{2}} \beta_{i}
$$

The explanatory variables used for the empirical analysis included information regarding four levels that are recognized in literature as determinants for the adoption of technology: producer, ranch, market, and context variables (Teaklewold et al., 2013; Guevas et al., 2013; Zuwarimwe and Mbaai, 2015). Two variables are associated with 
the producer: age (EDAD) and schooling (ESCOLARIDAD). The variables related to the ranch were: productivity measured in liters per cow per day (LITROS/VACA), number of animal units (UA), infrastructure (INFRAE), and machinery and equipment (MAQ). Economic or market variables such as income obtained from the sale of milk (LECHE) and income from the sale of calves (CARNE) were also included. In addition, context variables such as the distance from the ranch to the municipality (DIST) and the number of years with technical assistance (AT) that the producer has had were included. Therefore, the estimated empirical model was the following:

$$
\begin{aligned}
Y= & \beta_{0}+\beta_{1} X_{1}+\beta_{2} X_{2}+\beta_{3} X_{3}+\beta_{4} X_{4}+\beta_{5} X_{5} \\
& +\beta_{6} X_{6}+\beta_{7} X_{7}+\beta_{8} X_{8}+\beta_{9} X_{9}+\beta_{10} X_{10}+u_{i}
\end{aligned}
$$

Where: $Y=$ binary variable for the use of IA, $\beta_{i}=$ coefficients to be estimated, $X_{1}=\mathrm{EDAD}$; $X_{2}=\mathrm{ESCOL} ; X_{3}=\mathrm{LITROS} / \mathrm{VACA} ; X_{4}=\mathrm{UA} ; X_{5}=\mathrm{INFRAE} ; X_{6}=\mathrm{MAQ} ; X_{7}=\mathrm{LECHE} ;$ $X_{8}=\mathrm{CARNE} ; X_{9}=\mathrm{DIST} ; X_{10}=\mathrm{AT}$, and $u_{i}=$ stochastic error.

The information was captured in Excel spreadsheets; subsequently, the information was subject to a statistical analysis using the STATA program (StataCorp, 2015).

\section{RESULTS}

\section{Production units and significance of the model}

We interviewed producers that had an interest in the extension program: producers with extensive livestock production experience (the oldest producer interviewed was 85 years old), as well as young producers (21 years old) participated in the survey. In general, having a wide variability of participating producers is reflected in the descriptive statistics of the sample (Table 1).

In the producer-related variables, the average age identified was $50.94 \pm 13.84$ years, while the average schooling was $6.63 \pm 5.10$ years. It is important to point out that the

Table 1. Characterization of the production units analyzed.

\begin{tabular}{l|c|c|c}
\multicolumn{1}{c|}{ Variable } & Mean \pm SD & Minimum & Maximum \\
\hline Average age of Producers (years) & $50.94 \pm 13.84$ & 21 & 85 \\
\hline Producer schooling years & $6.63 \pm 5.10$ & 0 & 16 \\
\hline Average milk per cow & $2.63 \pm 2.07$ & 0 & 11.5 \\
\hline Animal units (AU) per ranch & $25.87 \pm 20.98$ & 4 & 194.3 \\
\hline Infrastructure index (\%) & $0.05 \pm 0.06$ & 0 & 0.36 \\
\hline Machinery and equipment index (\%) & $0.09 \pm 0.11$ & 0 & 0.54 \\
\hline Sale of milk per week $(\$)$ & $167.50 \pm 179.80$ & 0 & 1250 \\
\hline Sale of calves per year $(\$)$ & $28468.00 \pm 34042.00$ & 0 & 176000 \\
\hline Distance from the ranch to the municipality $(\mathrm{km})$ & $3.06 \pm 5.12$ & 0 & 40 \\
\hline Number of years with technical assistance & $1.44 \pm 2.33$ & 0 & 13 \\
\hline
\end{tabular}


participants included producers with undergraduate and even postgraduate studies, as well as producers who did not have any schooling. In the characteristics related to the production unit or ranches, a low average milk production $(2.63 \pm 2.07)$ was identified, as well as an average womb inventory level $(25.87 \pm 20.98)$ of animal units per ranch. With regard to the variables indirectly related to the capitalization level, very low infrastructure $(0.05 \pm 0.06)$ and machinery and equipment $(0.09 \pm 0.11)$ indexes were detected. In market-related variables, the income obtained from the sale of milk per week $(\$ 167.50 \pm \$ 179.80 \mathrm{MXN})$ was analyzed, as well as the income obtained from the sale of calves per year, which amounts to $\$ 28,468.00 \pm \$ 34,042.00 \mathrm{MXN}$. This seems to indicate that selling calves has preference over the production of milk. With regard to the context variables - those that do not depend on the production unit-, we recorded the distance in kilometers between the ranch and the municipal seat, as well as the years the producers had received technical assistance. Regarding this variable, is important to point out that the minimum value was 0 years and the maximum value was 13 years. On average, the distance from the ranches is $3.06 \pm 5.12 \mathrm{~km}$, while producers have had $1.44 \pm 2.33$ years of technical assistance (Table 1 ).

In the sample that we analyzed, only $4 \%$ of the farmers used IA technology. The $\mathrm{X}^{2}$ test was used to evaluate the global significance of the model; the null hypothesis was that all the coefficients of the equation (except for the constant) are null. The number of correctly predicted cases was $97.46 \%$, the $\mathrm{LR} \mathrm{Chi}^{2}(10)$ statistic was 46.87 , and the associated probability was $<0.000$; consequently, the null hypothesis is rejected and the global model is proved to be significant. The statistical significance of the estimated parameters was obtained through the Wald test (z-statistic). In the study, the IA was independent ( $p>0.05)$ of the schooling level and milk production per cow variables, as well of the income from milk sales and the average number of years that the producer had received technical assistance. In contrast, four variables were found to be significant $(p \leq 0.05)$ : age and distance from the ranch to the municipality have a negative influence in the decision to use IA, while the machinery and equipment index, as well as the sale of calves, have a positive influence in the decision of farmers to use this technology (Table 2).

The adoption of IA in the study region is negatively influenced by the age of the producer: older producers are $0.29 \%$ less likely to use IA technology. Meanwhile, the machinery index had a significant and positive conditional marginal effect ( $\mathrm{p} \leq 0.05)$; this result indicates that producers who had a higher level of machinery and equipment have a probability of adopting the IA of up to $36.43 \%$. In the same sense, the sale of calves was also significant and positive $(\mathrm{p} \leq 0.05)$, which showed that producers who sell calves are $0.00007 \%$ likely to adopt IA.

The coefficient of the distance variable was negative and significant $(\mathrm{p} \leq 0.05)$. Consequently, ranches located at a greater distance from the municipality are $2.3 \%$ less likely to adopt artificial insemination.

The objective of this work was to identify factors associated with the producer, production unit, income from product sales, and other context variables that determine the use of IA by cattle producers in northern Sinaloa. The results indicate that the IA was independent of variables related to the level of education, milk production per cow, income from milk 
Table 2. Coefficients of the variables that influence the probability of using artificial insemination.

\begin{tabular}{l|c|c|c|c}
\multicolumn{1}{c|}{ Variable } & Coefficient & $\mathbf{z}$ & $\mathbf{P}>\mathbf{z}$ & \multicolumn{1}{c}{$\mathbf{d y} / \mathbf{d x}$} \\
\hline Age & -0.192 & -2.04 & $0.042^{*}$ & \multicolumn{1}{c}{-0.0029} \\
\hline Producer schooling years & -0.281 & -0.18 & 0.853 & -0.0005 \\
\hline Average milk per cow & 0.373 & 1.43 & 0.153 & 0.005 \\
\hline Animal units (AU) per ranch & 0.020 & 0.84 & 0.402 & \multicolumn{1}{c}{.0003} \\
\hline Infrastructure index (\%) & -5.842 & -0.58 & 0.564 & -0.089 \\
\hline Machinery and equipment index (\%) & 23.886 & 2.41 & $0.016^{*}$ & 0.3643 \\
\hline Sale of milk per week (\$) & -0.0007 & -0.31 & 0.756 & -0.00001 \\
\hline Sale of calves per year $(\$)$ & 0.00004 & 0.043 & $0.043^{*}$ & 0.00000007 \\
\hline Distance from the ranch to the municipality $(\mathrm{km})$ & -1.553 & 2.03 & $0.023^{*}$ & -0.023 \\
\hline Number of years with technical assistance & -0.407 & -0.85 & 0.396 & -0.0005 \\
\hline Constant & -0.281 & -0.18 & 0.816 &
\end{tabular}

$\mathrm{dy} / \mathrm{dx}$ is the marginal effect of the $\mathrm{X}$ variable on the dependent $\mathrm{Y}$ variable; dy/dx significance level: $\mathrm{p}<0.05$

*. Number of observations (n): 200. LR $\operatorname{chi}^{2}(10)=46.87$; Prob $>\operatorname{chi}^{2}=0.0000$; Pseudo ${ }^{2}=0.7003$, correctly classified $=97.46 \%$.

sales, and the average number of years that the producer has had technical assistance. However, the age of the producer and the distance from the ranch to the municipality had a negative impact on the decision to use IA, while the machinery and equipment index and the sale of calves positively influenced the decision of farmers to use this technology. These results are discussed below.

The results obtained indicate that the distance from the production unit or the ranch is a determining factor for the use of IA and, the further away the production unit is from the municipality, the producer is less likely to adopt IA technology. Our results match the findings of Sirajuddin et al. (2018), who determined that location is important in the IA process, since the closer the ranch is to the inseminator, the greater the adoption of this practice. Not only are technical personnel more readily available when the producers are closer to the municipal seats, it is also possible to get supplies more quickly (pipettes, gloves, nitrogen, etc.). In other words, it seems that the use of IA is indeed related to a greater availability of the resources that can meet the requirements of this technology.

Additionally, the results indicate that the machinery and equipment index and the sale of calves are preponderant factors that contribute significantly to the adoption of IA. The use and adoption of IA has indeed many requirements, particularly knowledge/experience, personnel, and financial resources for the acquisition of inputs. Our results agree with reports that have indicated that the economic or purchasing factor plays a crucial role in the producer's decision to whether or not use IA (Howley et al., 2012; Cortés-Mora et al., 2014, Rathod et al., 2017; Lassala et al., 2020). It is also evident that age plays an important role in the adoption of technology; since older producers showed little interest in using or learning about IA technology. Therefore; the probability of adopting IA decreases inversely with the age of the producer.

The successful use of the IA technique requires that several factors occur simultaneously. Our results identify factors related to the producer and the productive unit (age, availability 
of machinery, sale of calves, distance from the ranch to the municipality) as determining factors in the use of this technology. These results complement previous reports that indicate that environmental factors, climate change, inadequate extension services, training, and limited financing reduce the use of IA in production units (Baruselli et al., 2019; Moreki et al., 2019). Taking into consideration the physiology of cows and the insemination technique is also necessary. Therefore, a successful heat detection, the technique used at the time of insemination, semen management (thaw and apply), the metabolic status, and the wellbeing of the cow are factors that can limit the success of IA (Yehalaw et al., 2018).

The animal units (UA) median for the interviewed producers was 21.6, which indicates - according to Cuevas et al. (2016) — that most of the producers analyzed belong to the small-scale producer stratum. This type of producer has a low level of resources, which undoubtedly limits the use of artificial insemination. The results match the findings of Cortés-Mora et al. (2012), Cuevas et al. (2013), Rangel et al. (2017, 2020) who indicate that there is a low technological level in the use of reproduction methods - such as artificial insemination or embryo transfer - in Latin America and that producers with greater purchasing or economic power are more likely to use IA, as reported in Latin America and Mexico by us and other authors (González-Quintero et al., 2020; Lassala et al., 2020).

Sectoral agricultural policies must be aligned with the needs of producers, in order to make production more efficient and to meet the demands for agricultural food production.

\section{GONGLUSIONS}

The age of the producer and the distance from the ranch to the municipal seat are variables that have a negative impact on the use of artificial insemination technology; in contrast, income from the sale of calves and the machinery and equipment index have a positive impact on the adoption of artificial insemination by producers from northern Sinaloa. Consequently, producers with a higher level of machinery and equipment have a probability of adopting IA of up to $36.43 \%$. Artificial insemination in the study region requires the definition of a technology diffusion and transfer policy that provides the different producers with permanent information about this technology, availability of inputs, and development of capacities. Only in this sense, the gaps in the use of this technology between small and large producers could be closed, thereby contributing to the improvement of livestock among the producers from northern Sinaloa.

\section{REFERENCES}

Baruselli, P.S., Ferreira, R.M., Sá Filho, M.F., Bó, G.A. (2018). Review: Using artificial insemination v. natural service in beef herds. Animal, (12): 45-52.

Baruselli, P.S., Catussi, B., de Abreu, L.Â., Elliff, F. M., da Silva, L. G., \& Batista, E. (2019). Challenges to increase the AI and ET markets in Brazil. Animal Reproduction, 16(3): 364-375.

Basurto, G.H., Martínez, A.A. y Gutiérrez, V.I. (1997). Factores que alteran la fertilidad de los servicios de inseminación artificial en vacas F1 (Holstein $\times$ Cebú) en el trópico húmedo. Veterinaria México, 28(2): $109-116$.

Cameron, A.C. and P.K. Trivedi. (2005). Microeconometrics: Methods and Applications. Cambridge University Press, New York. 
Casillas, T.O. (2012). Inseminación artificial de ganado bovino. Memoria. Disponible en https://www.fps.org.mx/ portal/index.php/publicaciones/103-pecuario/1233-inseminacion-artificial-de-ganado-bovino

Chará, J., Murgueitio, E., Uribe, F. \& Montoya, S. (2015). Carne sostenible con bienestar animal. Sistemas de carne. Cali, Colombia: Fundación CIPAV.

Cortés-Mora, J.A., A. Cotes-Torres y Cotes-Torres, J.M. (2012). Características estructurales del sistema de producción con bovinos doble propósito en el trópico húmedo colombiano. Revista Colombiana de Ciencias Pecuarias, 25: 229-239.

Cortés-Mora, J.A., Cotes-Torres, A., y Cotes-Torres, J.M. (2014). Avances en clasificación de sistemas de producción con bovinos doble propósito en Colombia. Archivos de Zootecnia, 63(243): 559-562.

Cuevas, R.V., Baca, M.J., Gervantes, E.F., García, E.J.A., Aguilar, A.J., Loaiza, M.A. (2013). Factores que determinan el uso de innovaciones tecnológicas en la ganadería de doble propósito en Sinaloa, México. Revista Mexicana de Ciencias Pecuarias, 4(1): 31-46.

Guevas, R.V., Loaiza, M.A., Espinosa, G.J.A., Vélez, I.A., \& Montoya, F.M.D. (2016). Tipología de las explotaciones ganaderas de bovinos doble propósito en Sinaloa, México. Revista Mexicana de Ciencias Pecuarias, 7(1): 69-83.

Cuevas-Reyes V. y Rosales-Nieto C. (2018). Caracterización del sistema bovino doble propósito en el noroeste de México: productores, recursos y problemática. Rev MVZ Córdoba, 23(1): 6448-6460.

González-Quintero, R., Barahona-Rosales, R., Bolívar-Vergara, D.M., Chirinda, N., Arango,J., Pantévez, H.A., Correa-Londoño, G., \& Sánchez-Pinzón, M.S. (2020). Technical and environmental characterization of dual-purpose cattle farms and ways of improving production: A case study in Colombia. Pastoralismo, 10, 19. https://doi.org/10.1186/s13570-020-00170-5

Greene W. (2003). Econometric analysis. 5a Ed. New Jersey: Prentice Hall.

Horrach, J.M.N., Bertot, V.J.A., Vázquez, M.O.R., \& Garay, D.M. (2020). Eficiencia reproductiva de sistemas vacunos en inseminación artificial. Tendencias actuales y perspectivas. Revista de Producción Animal, 32(3): 70-78.

Howley, P., Donoghue, O.C., \& Henaue, K. (2012). Factors Affecting Farmers' Adoption of Agricultural Innovations: A Panel Data Analysis of the Use of Artificial Insemination among Dairy Farmers in Ireland. Journal of Agricultural Science, 4(6): 171-179.

INEGI (Instituto Nacional de Estadística y Geografía). (2017). Anuario Estadístico del estado de Sinaloa. http:// estadisticas.sinaloa.gob.mx/Anuarios.aspx

INEGI (Instituto Nacional de Estadística y Geografía). (2019). Anuario estadístico y geográfico por entidad federativa 2018. Instituto Nacional de Estadística y Geografía. México: INEGI, 2019. https://www.inegi.org.mx/ app/biblioteca/ficha.html?upc $=702825107017$

Kubkomawa, H.I. (2018). The Use of Artificial Insemination (AI) Technology in Improving Milk, Beef and Reproductive Efficiency in Tropical Africa: A Review. Journal of Dairy E Veterinary Sciences, 5(2): 555660. https://doi.org/10.19080/JDVS.2018.05.555660

Lassala, A., Hernández, C.J., Pedernera, M., González-Padilla, E., y Gutiérrez, C.G. (2020). Cow-calf management practices in Mexico: Reproduction and breeding. Veterinaria México, 7(1). https://doi. org/10.22201/fmvz.24486760e.2020.1.839.

Loaiza, M. A. (2011). Tecnologías productivas para ganaderos de Sinaloa. Fundación Produce Sinaloa. http://www. fps.org.mx/portal/index.php/paquetes-tecnológicos/108-bovinos/1833-tecnologias-productivas-paraganaderos-de-sinaloa

Moreki, J.C., Pelaelo-Grand, T.D. \& Ranko, A. (2019). Artificial insemination in Botswana: Challenges and opportunities-A review. Journal of Animal Science and Veterinary Medicine, 4(4): 122-128.

Rathod, P., Chander, M. \& Sharma G.C. (2017). Adoption status of artificial insemination in Indian dairy sector: application of multinomial logit model. Journal of Applied Animal Research, 45: 442-446.

Rangel, J., J.A. Espinosa, G. De Pablos-Heredero, C. Barba, A. Vélez, J. Rivas y A. García. (2017). Adopción de innovaciones y prácticas organizativas de manejo, alimentación y reproducción en pequeñas unidades de producción de vacunos de doble propósito en México. Revista Científica, FCV-LUZ XXVII, 44-55.

Rangel, J., J. Perea, C. De-Pablos-Heredero, J.A. Espinosa-García, P. Toro-Mujica, M. Feijoo, C. Barba y A. García. (2020). Structural and technological characterization of tropical smallholder farms of dualpurpose cattle in Mexico. Animals, 10: 86. https://doi.org/10.3390/ani10010086

REDGATRO (RED DE GANADERÍA TROPICAL). (2018). Libro técnico. 2da Ed. CONACYT. https:// redgatro.fmvz.unam.mx/docs/Estado_arte.pdf

SIAP (Servicio de Información Agroalimentaria y Pesquera). (2020). Boletín trimestral sobre la producción de leche de bovino. http://infosiap.siap.gob.mx/opt/boletlech/Brochure\%20Cuarto\%20Trimestre\%202019.pdf 
Sirajuddin, S.N., Sudirman, I., Bahar, L. D., Al Tawaha, A. R., y Al Tawaha, A. R. (2018). Social economic factors that affect cattle farmer's willingness to pay for artificial insemination programs. Bulgarian Journal of Agricultural Science, 24(4): 574-580.

StataCorp. (2015). Stata Statistical Software: Release 14. College Station, TX: StataCorp LP.

Teklewold, H., Kassie M. \& Shiferaw B. (2013). Adoption of multiple sustainable agricultural practices in rural Ethiopia. Journal of Agricultural Economics, 64(3): 597-623.

Urdaneta, F. (2009). Mejoramiento de la eficiencia productiva de los sistemas de ganadería bovina de doble propósito (Taurus-Indicus). Archivos Latinoamericanos de Producción Animal, 17(3-4):109-120.

Yehalaw, B., Jemberu, A., Asnake, A., Wube, A. \& Hirpa, H. (2018). Factors affecting the efficiency of artificial insemination in dairy cows in and around Bishoftu (Debre Zeite), Oromia Regional State, Ethiopia. Journal of Reproduction and Infertility, 9(2): 28-35.

Zuwarimwe, J., \& Mbaai S.M. (2015). Factors influencing smallholder farmers' decisions to participate in livestock markets in Namibia. Journal of Development and Agricultural Economics, 7(7): 253-260. 